\title{
Shelf life prediction and Bacterial flora for the fresh and lightly salted Pseudosciaena crocea stored at different temperatures
}

\author{
Guo Quanyou1, Zhu Yanqi1 ${ }^{1,2}$, Wang Lumin ${ }^{1 *}$, Li Baoguo ${ }^{2 *}$, Jiang Chaojun1 \\ ${ }^{1}$ East China Sea Fisheries Research Institute, Chinese Academy of Fishery Sciences, Shanghai 200090, China, ${ }^{2}$ School of Medical Instrument \\ and Food Engineering, University of Shanghai for Science and Technology, Shanghai 200093, P. R. China
}

\section{A B S TR A C T}

\begin{abstract}
The active dominant spoilage organisms in the farmed Pseudosciaena crocea would cause short shelf life. This study focused on an identification of spoilage bacteria and the development of predictive model of shelf life in Pseudosciaena crocea both fresh and lightly salted during the storage at low, ambient and fluctuating temperature conditions. Microbiological, chemical changes in Pseudosciaena crocea were assessed to ensure the shelf life; Phenotypic and 16S rRNA were used to identified dominated strains from different conditions. Shelf life, remaining shelf life were predicted by predictive models including exponential, school-field and Square-root equation. The results showed that Shewanella spp. was the dominant organism at low temperature, while Vibrio spp. and Enterobacter were the dominant organisms at ambient and fluctuating temperatures. While the Proteus vulgaris, Vibrio alginolytica and serratia were the dominant group at low, ambient and fluctuating environment of the lightly salted Pseudosciaena crocea .The shelf-life of fresh Pseudosciaena crocea were $5.4 \sim 17.8$ days, 1.1 days and $4.6 \sim 9.3$ days under low, ambient and fluctuating temperature; while the shelf life of lightly salted Pseudosciaena crocea were 12.2 49.1days, 4.2day and 20.5 23.5 days under low, ambient and fluctuating temperature. The evaluation index showed that School-field model and Exponential model in fresh fish were better, Exponential model was better to predict the shelf life in lightly salted fish. The results can facilitated the establishment of spoilage bacterial Hazard Analysis Critical Control Point during the processing of the Pseudosciaena crocea products.
\end{abstract}

Keywords: Fresh and lightly salted; Pseudosciaena crocea; Dominant spoilage organisms; Shelf-life prediction; Storage temperature

\section{INTRODUCTION}

Psendosciaena crocea, or called Large Yellow Croaker(LYC), with succulent and nice flavor, is a kind of economic valuable fish species in East China Sea(Xie et al.,2011).Its common consumption patterns are fresh and lightly salted measures. However, due to its abundant proteins, spoilage bacteria is extremely easy to cause corruption, which leads to a relatively short shelf life compared the LYC with other marine fish products ( $\mathrm{Li}$ et al.,2012). It is well known that fresh fish spoilage is the result of microbial activity of Specific Spoilage Organisms (SSO), a fraction of the total fish microbial that degrades the fish into biochemical components, which is usually perceived the loss of fishy freshness by the consumer(Garcia et al.,2015). It is important to identify these organisms in order to indicate the shelf life of the product. Species of the genera Pseudomonas spp., Shewanella spp., Carnobacterium spp., Lactococcusare spp. were well known as SSOs in fish products(Dalgaard et al.,2003, Koutsoumanis et al.,2000, Nieminen et al.,2016). Currently, compare with the Bacterial colony morphology, cell morphology and physiological biochemical characteristics, the sequence analysis of the $16 \mathrm{~S}$ rRNA gene is the most common and accuracy methods for studying seafood microbial that grown on plates(Alfaro et al.,2013)

Fish quality and the growth of the (SSO) may be affected by many factors related to the environment, so it is important to explore a evaluation system through monitoring environmental conditions of the packaged foods during transport and storage to provide food

\footnotetext{
*Corresponding author:

Wang Lumin, East China Sea Fisheries Research Institute, Shanghai 200090, China, room 202, block 1, Jun gong road 300, shanghai, china.Email:Imwang@ecsf.ac.cn

Li Baoguo, School of Medical Instrument and Food Engineering, University of Shanghai for Science and Technology, Shanghai 200093, China; room 201 ,Complex building C, Jun gong road 516. Email:Ibaoguo@126.com
}

Received: 18 May 2017; $\quad$ Accepted: 07 January 2018 
quality and safety information, in order to guarantee food quality, reduce losses and consumer complaints(Heredia et al.,2009). The predictive microbiology is the theoretical basis of the development of the food safety Intelligent evaluation system, which takes the microorganisms in food as the object of study, use integrated mathematics, statistics and computer interdisciplinary (Palino,2007) to reflect the factors of microbial activity at external condition by mathematical model, which is an important point in food processing to ensure the quality and safety(Berger,2007). Predictive microbiology is using mathematical models to make the quantitative prediction of dynamic changes of harmful microbes in food under certain conditions(PéRez-RodríGuez et al.,2013), so it is not only a method for preventing food-borne pathogens from damaging the food products and an effective early alarming tool in the food safety, but also an effective means to prevent food quality from decreasing caused by spoilage. Compared with time-consuming and cumbersome traditional evaluation methods, the preservative and intelligent evaluation methods are fast, accurate, being able to optimize the preservation of aquatic products(Mcmeekin et al.,2008).

The aim of the present investigation was to determine (i) the shelf life by sensory, microbiological and chemical changes, (ii) the initial and spoilage microbial of fresh and lightly salted LYC during the storage by $16 \mathrm{~S}$ rRNA gene sequencing analysis and (iii) develop the mathematical models to predict and remain the shelf life, which can provide the supports for digital describing mechanics of targeted microorganism and intelligently evaluating the safety and risk of fishery products.

\section{MATERIALS AND METHODS}

\section{Materials and Storage}

The fresh samples were from Ningde City, Fujian Province Sandu Bay, use ice refrigerated trucks for transportation $\left(0 \sim 1{ }^{\circ} \mathrm{C}\right), 6 \sim 9 \mathrm{~h}$ delivered to the laboratory. The lightly salted samples were from NINGDE WEIJIAHAO company, $450 \mathrm{~g}$ products, which the salt content was $2.0 \%$, moisture content was $60 \%$ and water activity was around 0.96 with vacuum package.

After sample arrived at laboratories, then kept in low temperature $\left(0 \sim 10^{\circ} \mathrm{C}\right)$, into the precision low temperature incubator (MIR-553, Sanyo, Japan), set inside temperature $2 \sim 3{ }^{\circ} \mathrm{C}$ and timely add ice.

Fresh and lightly salted $L Y C$ are usually transported and stored with chilled chain, $0^{\circ} \mathrm{C}$ is often regarded as the reference temperature, $5^{\circ} \mathrm{C}$ is common cold storage temperature and $25^{\circ} \mathrm{C}$ is the ordinary ambient temperature, so both of the Fresh and lightly salted $\operatorname{LYC} 0^{\circ} \mathrm{C}, 5^{\circ} \mathrm{C}, 25$ ${ }^{\circ} \mathrm{C}$ was chosen to built the shelf life models. While Fresh samples were stored at $7,10^{\circ} \mathrm{C}$ which in the arrange of $0 \sim 25^{\circ} \mathrm{C}$ for verification, and fluctuating temperature (A: $4{ }^{\circ} \mathrm{C}(50 \mathrm{~h}) \rightarrow 10{ }^{\circ} \mathrm{C}(28.5 \mathrm{~h}) \rightarrow 5^{\circ} \mathrm{C}(48 \mathrm{~h})$.; B: $4{ }^{\circ} \mathrm{C}$ $(50 \mathrm{~h}) \rightarrow 10{ }^{\circ} \mathrm{C}(28.5 \mathrm{~h}) \rightarrow 15^{\circ} \mathrm{C}(24 \mathrm{~h}) \rightarrow 25^{\circ} \mathrm{C}(5 \mathrm{~h})$. for verification of the remaining shelf life models. While the lightly salted samples were stored $10^{\circ} \mathrm{C}, 15^{\circ} \mathrm{C}$ which in the arrange of $0 \sim 25^{\circ} \mathrm{C}$ for verification, and fluctuating temperature $\left(\mathrm{C}: 10{ }^{\circ} \mathrm{C}(96 \mathrm{~h}) \rightarrow 15^{\circ} \mathrm{C}(96 \mathrm{~h}) \rightarrow 5^{\circ} \mathrm{C}\right.$; $\mathrm{D}$ : $10^{\circ} \mathrm{C}(240 \mathrm{~h}) \rightarrow 5^{\circ} \mathrm{C}$. for verification of the remaining shelf life models, which the temperature were chosen according to the process simulation that may occur during transportation with the arrange $0 \sim 25^{\circ} \mathrm{C}$ and were the most common temperature in the daily life.

Took the low temperature samples every $24 \mathrm{~h}$, took the samples at ambient temperature and fluctuating temperature every $8 \mathrm{~h}$. Used the time temperature recorder (Test 175-T2, Testo, Germany, accuracy $\pm 0.5^{\circ} \mathrm{C}$, the range of $-20.0 \sim 70.0^{\circ} \mathrm{C}$ ) to measure the fish temperature.

\section{Sample Preparation}

According to the experiment plan and storage chain, took 3 parallel experiments under each temperature section, low temperature, ambient temperature and fluctuating temperature every time. Every time selected 3 fish randomly, take off the scales, gutted and gills of the fish and sterile cut along the spine, the flesh of fish were cut and broken with a homogenizer (basic panoramic, IUL, Spain) to the fish paste state and evenly divided into two parts for the total number of colonies (total viable counts, TVC), as well as volatile basic nitrogen (total volatile basic nitrogen, TVBN) measurement.(He et al.,2015)

\section{Test Method \\ Quality index}

TVBN measuring methods used the international method(Quanyou et al.,2006).

Bacterial count: Weigh the broken fish $10.0 \mathrm{~g}$, added $90 \mathrm{~mL}$ $0.1 \%$ Peptone sterile saline, after high-speed oscillation to 10 -fold dilution of fish paste, took three appropriate concentration of dilution $0.1 \mathrm{~mL}$, with automated microbiology plate spiral pipettes (Eddy Jet, IUL, Spain) was applied on nutrient agar medium and iron agar (iron agar, IA) flat surface, each dilution was applied two plates, cultivate at $25^{\circ} \mathrm{C}$ for $48 \mathrm{~h}$, counted the bacteria cultured on agar colonies.

TVBN and TVC were regarded as the index that can show the shelf life, when the TVC was over 7 or the TVBN 
was over $30 \mathrm{mg} 100^{-1} \mathrm{~g}^{-1}$, the products reached the end of its shelf life.

\section{Bacterial phenotypic Identification}

Took the plates at the end of the shelf life, chose the appropriate total number of colonies, colony flat on the whole plate or certain areas (usually $30 \sim 100 \mathrm{CFU}$ colonies), according to colony morphology, Gram stain, cell morphology, spores or without sports and oxidation/ fermentation characteristics, using bacteria classification grouping method, each colonies picked at least $2 \sim 3 \mathrm{CFU}$ colony, isolated and purified the colonies, cultured under $25^{\circ} \mathrm{C}$ for $24 \sim 48$ h. Bacterial colony morphology, cell morphology and physiological and biochemical characteristics were analyzed using Sensitire (trek diagnostic system Ltd, UK) and MIDI (MIDI Inc., Newark, Del, USA) classification multiphase systems, which divide the spoilage bacteria into several groups, choose the high proportion bacteria groups which the proportion was over $20 \%$ for further 16S rRNA gene partial sequence-based Identification.

16S rRNA gene partial sequence-based Identification A total of 12 pure cultures were chosen according 2.3.2 and recovered from TSA plates used for genetic Identification. Bacterial DNA extraction and purification were performed on pure cultures using the Bacterial Genomic DNA extraction kit (Sangon, China) according to the manufacturer's instructions and get the target 16S rRNA gene. The primers used for PCR were 27F (5'-AGAGT'TTGATCCTGGCTCAG-3') and 1492R (5'-CCC GGG AAC GTA TTC AC CG-3'), the final volume of the PCR mixture was $50 \mu$, which contained $1 \mu \mathrm{l}$ DNA, $5 \mu l 10 \times$ buffer, $1 \mu l \mathrm{MgCl}_{2}, 4 \mu \mathrm{dNTP}$, $1 \mathrm{U}$ of Taq polymerase $0.5 \mu \mathrm{l}, 27 \mathrm{~F} 1 \mu \mathrm{l}, 1492 \mathrm{R} 1 \mu \mathrm{l}$ and add $\mathrm{ddH}_{2} \mathrm{O}$ to $50 \mu \mathrm{l}($ Tiangen, China). Samples were analyzed in a Instrument for Polymerase Chain Reaction (Biometra, Goettingen, Germany) with the following program: $3 \mathrm{~min}$ at $94{ }^{\circ} \mathrm{C}, 35$ cycles of $30 \mathrm{~s}$ at $94{ }^{\circ} \mathrm{C}, 45 \mathrm{~s}$ at $50{ }^{\circ} \mathrm{C}$ and $100 \mathrm{~s}$ at $72{ }^{\circ} \mathrm{C}$ and a final step of $7 \mathrm{~min}$ at $72{ }^{\circ} \mathrm{C}$, cold down to 4 ${ }^{\circ} \mathrm{C}$. The products were than for gel electrophoresis at $110 \mathrm{v}$ for $30 \mathrm{~min}$ with $1 \%$ gel, and saw if there was a target band in the gel imager around 1500bp. The PCR products with target band were sent to Shanghai Biological Engineering technology Services Company for 16S rRNA sequencing. For the detection of closest relatives, all sequences were compared with the BLAST function on NCBI with $>99 \%$ relative result and then submit to NCBI which the submit number were showed in Fig 1. Sequence data were aliened and phonotypes were defined as the data showed $>99 \%$ similarity to each other. All relative unique phonotypes and sequences were obtained from GenBank, and the maximum likelihood statistical method was used to build phylogenetic tree through the MEGA7.0 software. Bootstrapping was performed with 500 replicates to assign confidence levels to the tree topology.
Effect of storage temperature on the shelf life of Pseudosciaena crocea Construction of the relative rate model of corruption Data on the rates of spoilage determined as the reciprocal of shelf-life (RS, day) from Fresh and lightly salted sampled were calculated and three empirical models: exponential model (1) school-field model (2)Square-root (3) were fitted to the combined RS-data. In this study the shelf life data of $0,5,25^{\circ} \mathrm{C}$ were used to built the RRS models.

$$
\begin{aligned}
& \operatorname{In}(R R S)=a \times\left(T-T_{\text {ref }}\right) \\
& \operatorname{In}(R R S)=\frac{-E_{a} \times 10^{3}}{R} \times\left(\frac{1}{T+273}-\frac{1}{T_{\text {ref }}+273}\right) \\
& \sqrt{R R S}=\frac{T-T_{\min }}{T_{\text {ref }}-T_{\min }}
\end{aligned}
$$

Where a is the coefficient; Ea is the in the apparent activation energy, $\mathrm{kJ} / \mathrm{mol}, \mathrm{T}$ is the storage temperature, $\mathrm{R}$ is $8.314 \mathrm{~J} /(\mathrm{mol} \cdot \mathrm{K}), T_{\min }$ is the temperature coefficient characteristics, the theoretical minimum temperature.

\section{Construction shelf life prediction model}

$L Y C$ are usually transported with chilled chain, $0^{\circ} \mathrm{C}$ is often regarded as the reference temperature of fresh fish during the storage period. Combined with the relative corruption rate which is defined through the experiment, developed Exponential, School-field and Square-root shelf life prediction model is as follows:

$$
S L_{T}=\frac{S L_{r e f}}{\exp [a T]}
$$

$S L_{T}=\frac{S L_{r e f}}{\exp \left[\frac{-E_{a}}{R} \times\left(\frac{1}{T+273}-\frac{1}{273}\right)\right]}$

$S L_{T}=\frac{S L_{r e f}}{\left(T / T_{\text {min }}+1\right)^{2}}$

Where $\mathrm{SL}_{\mathrm{T}}$ is the shelf life, $\mathrm{T}$, is the temperature, $\mathrm{R}$ is $8.314 \mathrm{~J} /(\mathrm{mol} \cdot \mathrm{K}), \mathrm{SL}_{\text {ref }}$ is the reference temperature

\section{Construction of the remaining shelf life prediction model}

To predict the remaining shelf life, the time-temperature history is divided into a very short time under the set temperature interval, the time experienced at different temperatures is converted to a reference temperature $0^{\circ} \mathrm{C}$, The difference of shelf life under the reference temperature was calculated, so that it could export the remaining shelf life at different temperatures as equations: 


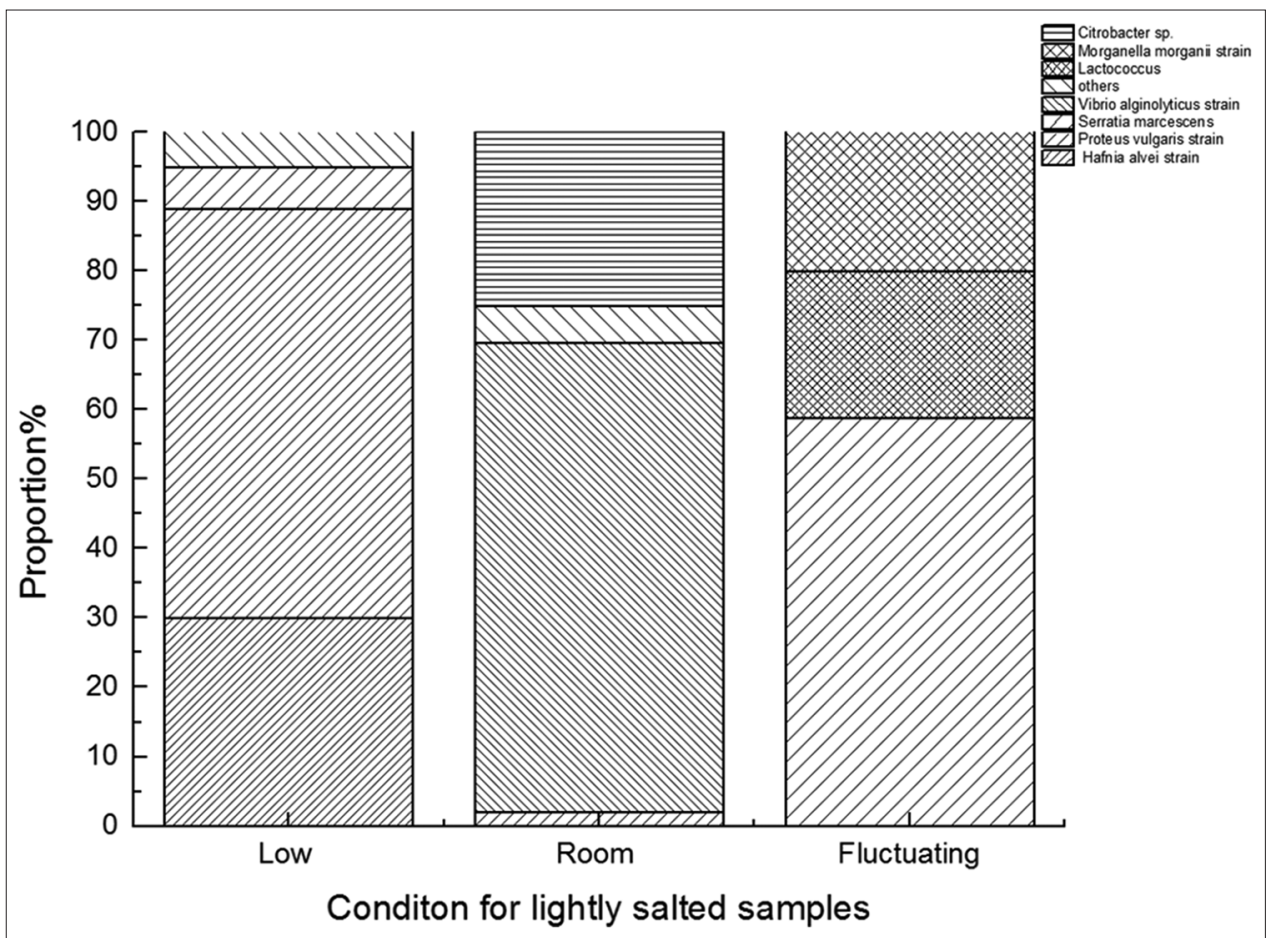

Fig 1. The proportion of the bacteria in fresh and lightly salted samples

$R S L_{T}=\frac{S L_{T_{\text {ref }}}-\sum_{i=1}^{n}\left(S T_{n} \times R R S_{T_{n}}\right)}{\exp (a \times T)}$

$R S L_{T}=\frac{S L_{T_{\text {ref }}}-\sum_{i=1}^{n}\left(S L_{T_{n}} \times r r S_{T_{n}}\right)}{\exp \left[\frac{-E_{a} \times 10^{3}}{R} \times\left(\frac{1}{T+273}-\frac{1}{T_{\text {ref }}+273}\right)\right]}$

$R S L_{T}=\frac{S L_{T_{\text {ref }}}-\sum_{i=1}^{n}\left[S L_{T_{n}} \times R R S_{T_{n}}\right]}{(1+a \times T)^{2}}$

Where $\mathrm{RSL}_{\mathrm{T}}$ is the remaining shelf life of the temperature $\mathrm{T}, \mathrm{SL}_{\text {Tref }}$ is the shelf life of the temperature $\mathrm{T}_{\text {ref }}$ which is the reference temperature shelf life; $\mathrm{ST}_{\mathrm{Tn}}$ is the storage time of the temperature $T_{n}, R_{R S}$ Tn relative corruption rate of the temperature $T_{n}$.

\section{Data Processing}

Viable counts, kinetic parameters $\left(\mu_{m}, \operatorname{lag}\right)$, TVBN, values were statistically tested by SPSS(21.0). The data of sequence-based Identification was used MEGA7.0 and all the pictures were made by origin 9.0 .

\section{Evaluation Model}

To compare the performance of the model, the most effective means is to detecting the difference between the predicted value and the real data, the coefficient of determination $\mathrm{R}^{2}$, residual sum of squares (residual sum of squares, RSS), the degree of deviation (bias factor, $\mathrm{BF}$ ), accuracy (accuracy factor, AF), RMSE (root mea n square error, RMS) goodness of fit of the model (goodness of fit) were evaluated. In this study the data in 7,10,15 and fluctuating temperature were used for Evaluation.

$$
\begin{aligned}
& R S S=\sum_{i=1}^{n}\left(x_{p}-x_{0}\right)^{2} \\
& B F=10^{\sum_{i=1}^{n} \lg \left(x_{p} / x_{0}\right)} n
\end{aligned}
$$

$A F=10^{\sum_{i=1}^{n}\left|\lg \left(x_{p} / x_{0}\right)\right|}$

$R M S=\sqrt{\frac{\sum_{i=1}^{n}\left(x_{p}-x_{0}\right)}{n}}$

In the formula, $\mathrm{n}$ is the number of sample, $x_{p}$ and $x_{0}$ were predicted and actual values.

\section{RESULTS}

Quality characters of the initial and chemical changes Tab.1 showed the evolutionary TVC of fresh and lightly salted $L Y C$ which stored at different temperatures. Respectively, TVBN values increased throughout the storage. As expected, the rate of change of the chemical 
indicator was higher at high temperature than at low temperature. The freshness lost gradually in LYC is dependent on its own physiological, biochemical, microbiological and other factors, so evaluating quality characteristics is essential to reduce the risk of corruption during the supply chain. From Table 1, provided the initial storage of fresh and lightly salted LYC samples, TVBN were $(8.04 \pm 1.07)$ and $(8.93 \pm 1.07) \mathrm{mg} / 100 \mathrm{~g}$ and the total number of colonies of bacteria were $(4.21 \pm 0.25)$ and (5.72 \pm 0.25$) \lg (\mathrm{CFU} / \mathrm{g})$, obviously the light salted samples value was higher. Besides, at low temperature $\left(0 \sim 10{ }^{\circ} \mathrm{C}\right)$, the total number of colonies of bacteria were $(6.63 \sim 6.72)$ and $(6.03 \sim 7.98) \mathrm{mg} / 100 \mathrm{~g}$ at the end of shelf life storage, while at ambient temperature storage of fresh and lightly salted LYC, the total number of colonies of bacteria were $(6.51 \pm 0.24)$ and $(7.12 \pm 0.33) \lg (\mathrm{CFU} / \mathrm{g})$, TVBN were $(24.03 \pm 0.38)$ and $(30.84 \pm 0.25) \mathrm{mg} / 100 \mathrm{~g}$.

Due to the different spoilage bacterial activity during the storage, there were significant differences between the fresh and lightly salted samples in TVC and TVBN (Sig1>0.05). So that Bifidobacterium classification grouping method and 16s RNA were both used for deep identification.

\section{IDENTIFICATION OF THE SPOILAGE MICROBIOLOGY}

\section{Indigenous microbiology Microbiological analysis and 16S rRNA gene partial sequence-based identification} At the end point of shelf lives of fresh samples, from $0 \sim 10{ }^{\circ} \mathrm{C}, 280$ bacteria were isolated; from $25{ }^{\circ} \mathrm{C}$ and fluctuating temperature 81 and 63 strains were isolated and identified.

The results showed in Figs. 1 and 2, at low temperature $\left(0 \sim 10^{\circ} \mathrm{C}\right)$ Shewanella (Shewanellaputrefaciens) was the specific spoilage bacteria, the bacterial ratio was $67.5 \%$, and the result was the same as Birte FV(Vogel et al.,2005) reported that the Shewanella existing in seawater was the main spoilage bacterial of fish in cold storage. And at $25^{\circ} \mathrm{C}$, the proportion of Vibrio (Vibronaceae) and Enterobactershare were $53.1 \%$ and $25.9 \%$, while at the fluctuating temperature, Vibrio (Vibronaceae)was the dominant group with the ratio of $42.9 \%$. At the end of storage, Shewanella, Enterobacter and Vibrio grew significantly, which mainly caused the spoilage of the fresh samples.

At the end of shelf lives of lightly salted samples, from $0 \sim 15^{\circ} \mathrm{C}, 150$ bacteria were isolated, from $25^{\circ} \mathrm{C}$ and fluctuating temperature, both 50 strains were isolated and identified. The results were showed in Figs. 1 and 3, at low temperature $\left(0 \sim 15^{\circ} \mathrm{C}\right)$ Proteus vulgaris was the specific spoilage bacteria, the bacterial ratio was $58.9 \%$, at $25^{\circ} \mathrm{C}$, Vibrio alginolytica shared the proportion of $67.64 \%$.While at the fluctuating temperature, serratia was the dominant group with the ratio of $58.8 \%$, which mainly caused the spoilage of lightly salted samples.

\section{SHELF-LIFE AND PREDICTION MODEL}

\section{Construction and verification of the relative rate model of corruption}

From the quality characteristics, chemical and microbiological changes, the shelf life of fresh samples was 5.4 17.8 days $\left(0-10^{\circ} \mathrm{C}\right), 1.1$ days $\left(25^{\circ} \mathrm{C}\right)$ and $4.6 \sim 9.3$ days (Fluctuating temperature); the shelf life of lightly salted samples was $12.2 \sim 49.0$ days $\left(0-15^{\circ} \mathrm{C}\right), 4.2$ days $\left(25^{\circ} \mathrm{C}\right)$ and 20.5 23.5 days (Fluctuating temperature). So it showed that salted progress can extend the shelf life of the fresh samples.

According to the measured data of shelf life, three RRS model formulas in Table 3 were used to derive the relative corruption rate of RRS data at $0^{\circ} \mathrm{C} \sim 25^{\circ} \mathrm{C}$ (Table 2). Regarded $0^{\circ} \mathrm{C}$ as the reference temperature and chose $0^{\circ} \mathrm{C}, 5^{\circ} \mathrm{C}$ and $25^{\circ} \mathrm{C}$ RRS data to fit the Exponential, School-field and Square-root RRS models which were

Table 1: Quality characters of the initial and the end of shelf life of $L Y C$ stored at different temperature

\begin{tabular}{|c|c|c|c|c|c|c|c|}
\hline $\begin{array}{l}\text { Storage } \\
\text { condition/ } \\
\text { fresh } \\
\text { samples }\end{array}$ & $\begin{array}{c}\text { Temperature/ } \\
{ }^{\circ} \mathrm{C}\end{array}$ & $\begin{array}{c}\text { TVCI } \\
\text { Ig }\left(\mathrm{CFUg}^{-1}\right)\end{array}$ & 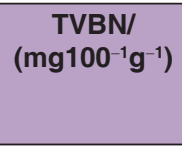 & $\begin{array}{l}\text { Storage condition } \\
\text { /lightly salted } \\
\text { samples }\end{array}$ & $\begin{array}{c}\text { Temperature/ } \\
{ }^{\circ} \mathrm{C}\end{array}$ & TVC/lg (CFUg $\left.{ }^{-1}\right)$ & 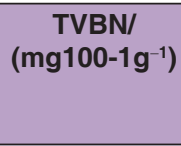 \\
\hline Initial & - & $4.21 \pm 0.25$ & $8.04 \pm 1.07$ & initial & - & $5.72 \pm 0.25$ & $8.93 \pm 1.07$ \\
\hline \multirow{4}{*}{$\begin{array}{l}\text { Low } \\
\text { temperature }\end{array}$} & 0 & $6.64 \pm 0.49$ & $30.12 \pm 2.06$ & Low temperature & 0 & $6.037 \pm 0.49$ & $30.24 \pm 0.84$ \\
\hline & 5 & $7.60 \pm 0.25$ & $29.58 \pm 3.19$ & & 5 & $7.98 \pm 0.25$ & $30.56 \pm 0.19$ \\
\hline & 7 & 6.63 & 26.3 & & 10 & 6.64 & 29.66 \\
\hline & 10 & 6.72 & 28.26 & & 15 & 7.6 & 31.08 \\
\hline Ambient & 25 & $6.51 \pm 0.24$ & $24.03 \pm 0.38$ & Ambient & 25 & $7.12 \pm 0.33$ & $30.84 \pm 0.25$ \\
\hline \multirow[t]{2}{*}{$\begin{array}{l}\text { Fluctuating } \\
\text { temperature }\end{array}$} & A & $7.23 \pm 0.01$ & $27.40 \pm 0.04$ & $\begin{array}{l}\text { Fluctuating } \\
\text { temperature }\end{array}$ & C & $7.92 \pm 0.21$ & $29.23 \pm 0.44$ \\
\hline & B & $6.67 \pm 0.01$ & $26.42 \pm 0.09$ & & D & $7.95 \pm 0.33$ & $30.1 \pm 0.13$ \\
\hline
\end{tabular}




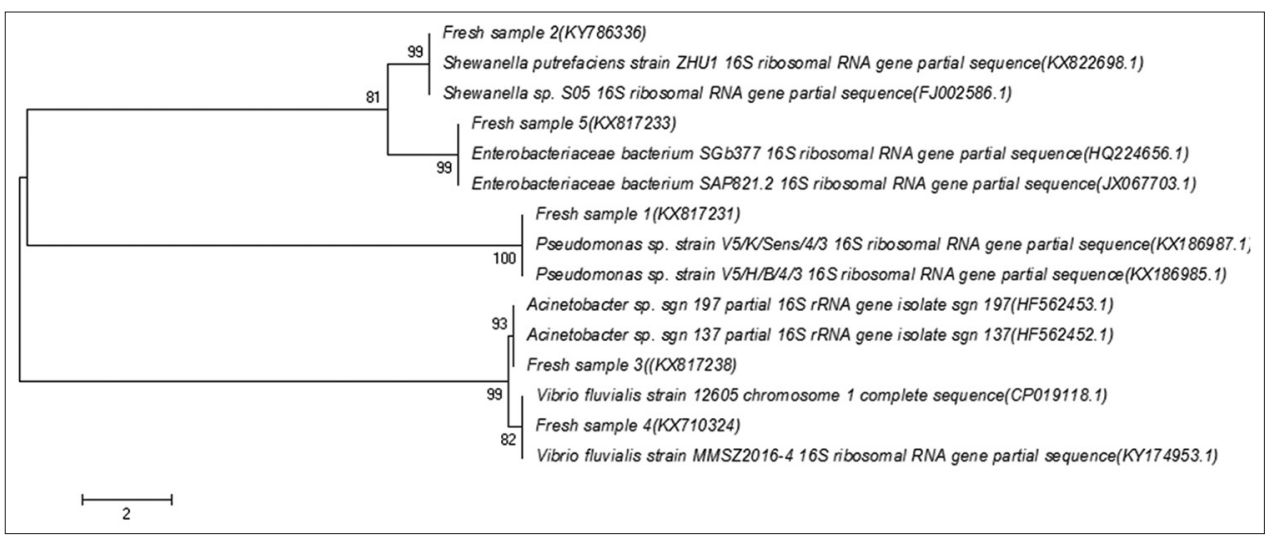

Fig 2. Phylogenetic analysis for fresh samples

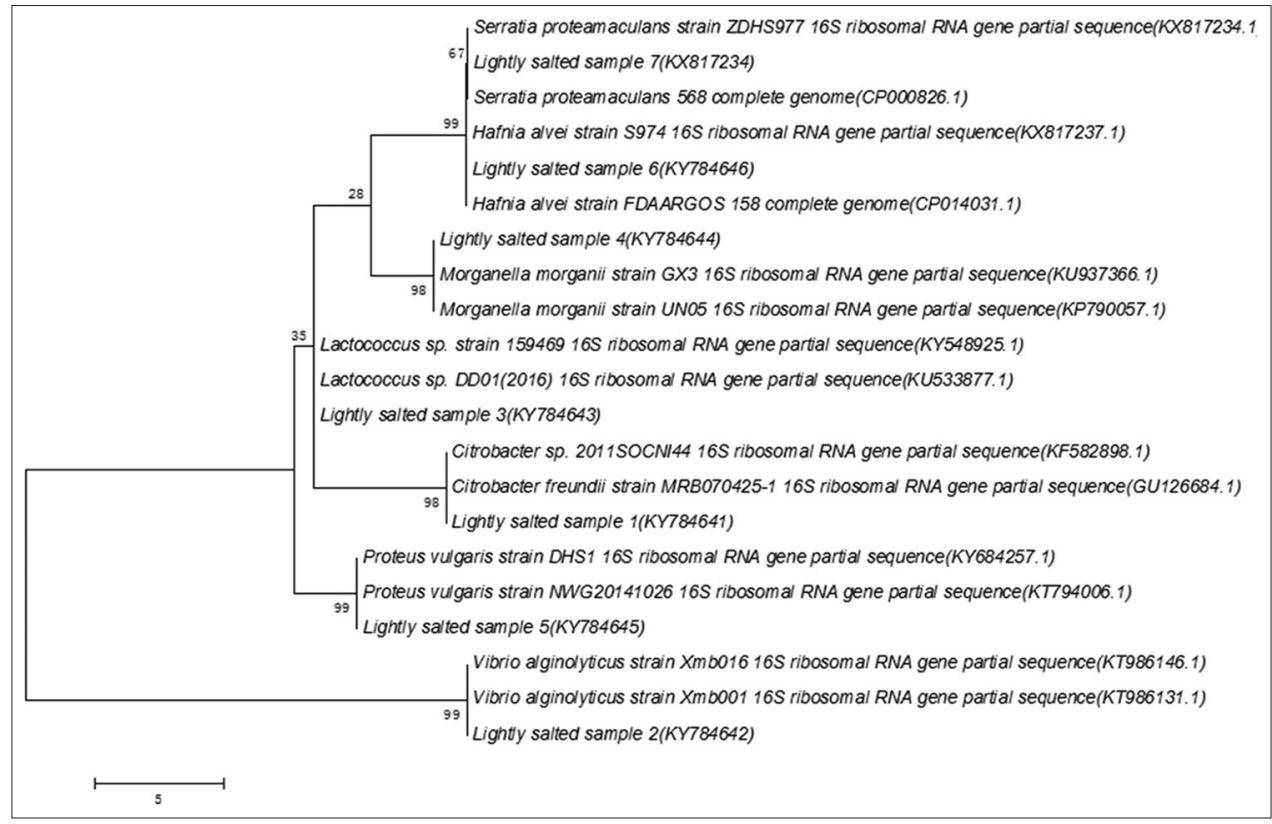

Fig 3. Phylogenetic analysis for lightly salted samples

Table 2: Validation on shelf life predictive models of Pseudosciacna crocea stored under different temperatures

\begin{tabular}{|c|c|c|c|c|c|c|c|}
\hline $\begin{array}{l}\text { Storage } \\
\text { conditions/ } \\
\text { fresh } \\
\text { samples } \\
\end{array}$ & Temperature $/{ }^{\circ} \mathrm{C}$ & Shelf-life/d & $\begin{array}{l}\text { Relative } \\
\text { corruption } \\
\text { rate }\end{array}$ & $\begin{array}{l}\text { Storage } \\
\text { conditions/lightly } \\
\text { salted samples }\end{array}$ & Temperature $/{ }^{\circ} \mathrm{C}$ & Shelf-life/d & $\begin{array}{l}\text { Relative } \\
\text { corruption } \\
\text { rate }\end{array}$ \\
\hline \multirow{5}{*}{$\begin{array}{l}\text { Low } \\
\text { temperature }\end{array}$} & 0 & $17.8 \pm 2.5$ & 1 & Low temperature & 0 & $49 \pm 1.1$ & 1 \\
\hline & 5 & $9.3 \pm 1.1$ & 1.91 & & 5 & $29.1 \pm 1.0$ & 1.684 \\
\hline & 7 & 7.2 & 2.47 & & 10 & 18.5 & 2.65 \\
\hline & 10 & 5.4 & 3.24 & & 15 & 12.2 & 4.016 \\
\hline & Total & $5.4 \sim 17.8$ & - & & Total & $12.2 \sim 49.0$ & - \\
\hline $\begin{array}{l}\text { Ambient } \\
\text { temperature }\end{array}$ & 25 & 1.1 & 14.8 & $\begin{array}{l}\text { Ambient } \\
\text { temperature }\end{array}$ & 25 & 4.2 & 11.667 \\
\hline \multirow[t]{3}{*}{$\begin{array}{l}\text { Fluctuating } \\
\text { temperature }\end{array}$} & A & 9.3 & - & $\begin{array}{l}\text { Fluctuating } \\
\text { temperature }\end{array}$ & C & 20.5 & - \\
\hline & B & 4.6 & - & & $\mathrm{D}$ & 23.5 & - \\
\hline & Total & $4.6 \sim 9.3$ & - & & Total & 20.5 23.5 & - \\
\hline
\end{tabular}

showed in Table 3 , resulted that the model parameters: the temperature characteristic coefficient $\mathrm{a}_{1}=0.11$ and $\mathrm{a}_{2}=0.098 ; \mathrm{Ea}_{1}=74.00 \mathrm{~kJ} / \mathrm{mol}$ and $\mathrm{Ea}_{2}=66.44 \mathrm{~kJ} / \mathrm{mol} ;$ $\operatorname{Tmin}_{1}=-10.00^{\circ} \mathrm{C}$ and $\operatorname{Tmin}_{2}=-10.52^{\circ} \mathrm{C}$. 
The Evaluation of predictive performance of models In this study, the data at $7,10,15^{\circ} \mathrm{C}$ were used for RRS model evaluation. Use the BF, AF, RSS and RMS to evaluate the performance of RRS Exponential, School-field and Square-root model. Since the BF of these 3 models were 0.75-1.25, showed the model was acceptable to fresh samples and lightly salted samples in Table 4. Besides, AF of these models were all $<1.30$, which also indicated the results were acceptable. Including AF, BF, RSS and RMS and other evaluation parameters, three kinds of equations were acceptable, the RSS and RMS parameters of Schoolfield RRS model were the lowest for fresh LYC, and the RSS and RMS parameters of Exponential RRS model were the lowest. So the result indicated that the performance of School-field RRS model was superior to Exponential RRS model and Square-root RRS model in fresh samples, while the Exponential RRS model showed great good of fitness in lightly salted samples.

\section{Construction and validation of the shelf life predictive model}

According to the parameters of the RRS models, the formulas from 4 to 6 were used to predict the shelf life of fresh fish at 7 and $10^{\circ} \mathrm{C}$, and at 10 and $15^{\circ} \mathrm{C}$ of lightly salted fish. The predicted values were compared with the observed data. Table 5 showed the predicted values of the Exponential, School-field and Square-root shelf life prediction model, and their relative error in fresh samples were $7.3 \%$ and $13.03 \%, 1.8 \%$ and $9.38 \%,-18.2 \%$ and $-14.45 \%$, respectively, indicating that the formula Exponential model and the School-field model could better predict the shelf life of the fresh product at a constant temperature than the Square-root model. For the lightly salted samples, their relative error were $-0.90 \%$ and $-8.30 \%,-12.56 \%$ and $-5.85 \%,-31.8 \%$ and $-30.40 \%$, indicating that the formula Exponential model could better predict the shelf life of the lightly salted sample than the other two models. It was shown that the three models were different when used to predict the shelf life in the two kinds of fish samples.

\section{Development and validation of the remaining shelf life prediction model}

According to the parameters of the RRS models, the formulas from 7 to 9 were used to predict the remaining

Table 3: RRS model for fresh/light salted samples

\begin{tabular}{lccccc} 
& $\begin{array}{c}\text { RRS model for fresh } \\
\text { samples }\end{array}$ & $\mathbf{R}^{2}$ & RMSE & $\begin{array}{c}\text { RRS model for lightly salted } \\
\text { samples }\end{array}$ & $\mathbf{R}^{2}$ \\
\hline Exponential & $\operatorname{In}(R R S)=0.11 \times T$ & 0.99 & 0.07 & $\operatorname{In}(R R S)=0.098 \times T$ & 0.99 \\
School-field & $\operatorname{In}(R R S)=\frac{-74 \times 10^{3}}{8.314} \times$ & 0.99 & 0.03 & $\operatorname{In}(R R S)=\frac{-66.44 \times 10^{3}}{8.314} \times$ & 1 \\
& $\left(\frac{1}{T+273}-\frac{1}{273}\right)$ & & & $\left(\frac{1}{T+273}-\frac{1}{273}\right)$ & 0.003 \\
Square-root & $\sqrt{R R S}=0.1 \times T+1$ & 0.96 & 0.21 & $\sqrt{R R S}=0.095 \times T+1$ & 0.99 \\
\hline
\end{tabular}

Table 4: Evaluation of predictive performance of three RRS models

\begin{tabular}{|c|c|c|c|c|c|c|c|c|c|c|c|c|c|}
\hline \multirow{2}{*}{$\begin{array}{l}\text { RRS Model } \\
\text { of fresh } \\
\text { samples }\end{array}$} & \multicolumn{6}{|c|}{ RRS predict value } & \multirow{2}{*}{$\begin{array}{l}\text { RRS Model } \\
\text { of lightly } \\
\text { salted } \\
\text { samples }\end{array}$} & \multicolumn{6}{|c|}{ RRS predict value } \\
\hline & $7^{\circ} \mathrm{C}$ & $10^{\circ} \mathrm{C}$ & BF & AF & RSS & RMS & & $10^{\circ} \mathrm{C}$ & $15^{\circ} \mathrm{C}$ & BF & AF & RSS & RMS \\
\hline Exponential & 2.15 & 2.98 & 0.928 & 1.077 & 0.36 & 0.347 & Exponential & 2.678 & 4.382 & 1.033 & 1.033 & 0.135 & 0.212 \\
\hline School-field & 2.26 & 3.17 & 0.963 & 1.038 & 0.049 & 0.127 & School-field & 2.813 & 4.593 & 1.067 & 1.067 & 0.359 & 0.346 \\
\hline Square-root & 2.89 & 4 & 1.13 & 1.13 & 0.754 & 0.501 & Square-root & 3.81 & 5.89 & 1.116 & 1.156 & 4.857 & 1.272 \\
\hline
\end{tabular}

Table 5: Validation on shelf life predictive models of fresh and lightly salted $L Y C$ stored aerobically under isothermal conditions

\begin{tabular}{|c|c|c|c|c|c|c|c|}
\hline \multirow[t]{2}{*}{ Models } & \multicolumn{7}{|c|}{ Shelf life prediction (days) for fresh samples } \\
\hline & $7^{\circ} \mathrm{C}$ & Relative error\% & $10^{\circ} \mathrm{C}$ & Relative error \% & $\mathbf{R}^{2}$ & RMSE & RMS \\
\hline Exponential & 8.279 & 13.03 & 5.973 & 7.3 & 0.995 & 0.07 & 0.705 \\
\hline School-field & 7.876 & 9.38 & 5.615 & 1.8 & 0.999 & 0.004 & 0.41 \\
\hline Square-root & 6.159 & -14.45 & 4.45 & -18.2 & 0.961 & 0.22 & 0.814 \\
\hline \multirow[t]{2}{*}{ Models } & \multicolumn{7}{|c|}{ Shelf life prediction (days) for lightly salted samples } \\
\hline & $10^{\circ} \mathrm{C}$ (days) & Relative error \% & $15^{\circ} \mathrm{C}$ & Relative error \% & $\mathbf{R}^{2}$ & RMSE & RMS \\
\hline Exponential & 18.334 & -0.9 & 11.18 & -8.3 & 1 & 0.021 & 0.483 \\
\hline School-field & 17.417 & -5.85 & 10.667 & -12.56 & 1 & 0.004 & 0.992 \\
\hline Square-root & 12.859 & -30.4 & 8.311 & -31.8 & 0.991 & 0.128 & 3.891 \\
\hline
\end{tabular}

Note: relative error $=\left(\mathrm{S}_{\text {Lprd }}-\mathrm{S}_{\text {Lobs }}\right) \times 100 \% / \mathrm{S}_{\text {Lobs }}$ 
shelf life of the fresh and lightly salted fish. After resuming A (fresh fish): $4^{\circ} \mathrm{C}(50 \mathrm{~h}) \rightarrow 10^{\circ} \mathrm{C}(28.5 \mathrm{~h}) \rightarrow 5^{\circ} \mathrm{C}(143 \mathrm{~h})$, the final shelf life was $9.3 \mathrm{~d}$. The equations from 7 to 9 were used to calculate remaining shelf life at different temperatures with the range of $0 \sim 25^{\circ} \mathrm{C}$, the shelf life of the predicted value in this invention of three models were 9.6, 9.2 and $7.3 \mathrm{~d}$, relative error of $3.3 \%,-0.9 \%$ and $-22.1 \%$, showed in Table 6 . After resuming $\mathrm{B}$ (fresh fish $) 4^{\circ} \mathrm{C} \quad(50 \mathrm{~h}) \rightarrow 10^{\circ} \mathrm{C} \quad(28.5 \mathrm{~h}) \rightarrow 15^{\circ} \mathrm{C} \quad(24 \mathrm{~h}) \rightarrow$ $25^{\circ} \mathrm{C}(5 \mathrm{~h})$ and finally arrived the end of shelf life (4.6d), the remaining shelf life prediction value were 4.6, 4.7 and $4.5 \mathrm{~d}$, relative errors were $0 \%, 0.2 \%$ and $0.2 \%$ (Table 6 ). By comparison of the relative error of the remaining shelf life prediction model of these three kinds, it showed the performance of Exponential and School-field remaining shelf life were much more excellent, which could quickly and efficiently predict the remaining shelf life of a range of $0 \sim 25^{\circ} \mathrm{C}$ of the fresh fish. The lightly salted samples after resuming $\mathrm{C}\left(\mathrm{C}: 10^{\circ} \mathrm{C} \quad(96 \mathrm{~h}) \rightarrow 15^{\circ} \mathrm{C} \quad(96 \mathrm{~h}) \rightarrow 5^{\circ} \mathrm{C}\right.$ ), finally reached the end of shelf life with 20.5 days; and 23.5 days of storage in the treatment of $\mathrm{D}\left(10^{\circ} \mathrm{C}(240 \mathrm{~h})\right.$ $\rightarrow 5^{\circ} \mathrm{C}$ ), and the relative errors of Exponential remaining shelf life prediction model was the lowest $(0.97$ and $6.5 \%)$, which meant that these models could best predict the remaining shelf life of the lightly salted samples within the range of $0 \sim 25^{\circ} \mathrm{C}$.

\section{DISCUSSION}

The present study aimed at evaluating the quality change of $L Y C$ stored at different temperature conditions with different treatments. The initial total aerobic counts obtained in this study (4.21 $\log \mathrm{CFU} / \mathrm{g}$ ) were quite similar to the raw Atlantic salmon stored at $4{ }^{\circ} \mathrm{C}, 10^{\circ} \mathrm{C}, 21^{\circ} \mathrm{C}$ (Miks-Krajnik et al.,2016), but higher than those reported by Zhu (Zhu et al.,2016) around $3.55 \log \mathrm{cfu} / \mathrm{g}$, and reaching up to $7.61 \log \mathrm{cfu} / \mathrm{g}$ after
5 days in $4^{\circ} \mathrm{C}$ LYC. $\backslash$ In this study the total average aerobic counts, while reaching up to 7.60, 6.51 and 7.23 at low, room and variable temperature in this paper, among the range of 6-9 $\log \mathrm{CFU} / \mathrm{g}$, which are always used as a reference method of shelf life estimation(Miks-Krajnik, et al.,2016, Zhu, et al.,2016). As for the fresh and lightly salted $L Y C$, respectively, the product had a much longer shelf life between 5.4 17.8 and 12.2 49.0 days under low temperature, while only 1.1day and 4.2days under ambient temperature and 4.6 9.3 and 20.5 23.5days under the fluctuating temperature. Which was similar to other research, J. Emborg(Emborg et al.,2002) explored the Microbial spoilage and formation of biogenic amines in fresh and thawed modified atmosphere-packed salmon (Salmosalar) which showed it could keep 14 21days at $2^{\circ} \mathrm{C}$. And Dalgaard (Dalgaard et al.,2006)found the shelf life was 15 days, 9 days in raw chilled garfish under air condition at $0^{\circ} \mathrm{C}$ and $5^{\circ} \mathrm{C}$. It could be concluded that the shelf life and the total aerobic counts were highly relative to the storage temperature, lower temperature could keep a longer shelf life but the total aerobic counts at the end of storage had no obviously difference among the different storage temperature. And Salt processing could keep the product for a longer shelf life.

For raw fish stored aerobically, many bacteria were regarded as potential SSOs, including Pseudomonas spp., Shewanella putrefaciens, Photobacterium phosphoreum, psychrotolerant bacteria, Serratia spp., Yersinia spp.(Alfaro,Hernandez,2013, Emborg et al.,2005, Koutsoumanis,Nychas,2000, Zhu, et al.,2016). The comparison were showed in Table 7.With 16S rRNA gene sequencing, it was confirmed that Shewanella was the predominant genera in the spoiled sample according to microbial count under low temperature, which was similar to the report by GU (Gu et al.,2013)and ZHU(Zhu, et al.,2016). The Shewanella genus currently includes 48 identified species. $S$. baltica and $S$. putrefaciens were the two main spoiling species of Shewanella in LYC, which are typical SSOs in fresh marine

Table 6: Remaining Shelf life predictive models of fresh/lightly salted samples stored under non-isothermal conditions

\begin{tabular}{|c|c|c|c|c|c|c|c|}
\hline \multirow[t]{2}{*}{$\begin{array}{l}\text { Temperature } \\
\text { changes }\end{array}$} & \multirow[t]{2}{*}{ Slobs/d } & \multicolumn{2}{|c|}{$\begin{array}{l}\text { Exponential (remaining shelf } \\
\text { life prediction model) }\end{array}$} & \multicolumn{2}{|c|}{$\begin{array}{l}\text { School-field (remaining shelf } \\
\text { life prediction model) }\end{array}$} & \multicolumn{2}{|c|}{$\begin{array}{l}\text { Square-root (remaining shelf } \\
\text { life prediction model) }\end{array}$} \\
\hline & & $S L_{\text {pre }} / \mathrm{d}$ & Relative error $/ \%$ & $S L_{\text {pre }} / \mathrm{d}$ & Relative error $/ \%$ & $S L_{\text {pre }} / \mathrm{d}$ & Relative error $/ \%$ \\
\hline A & 9.3 & 9.6 & 3.3 & 9.2 & -0.9 & 7.3 & -22.1 \\
\hline B & 4.6 & 4.6 & 0 & 4.7 & 0.2 & 4.5 & -0.2 \\
\hline C & 20.5 & 20.7 & 0.97 & 19.5 & 4.87 & 12.71 & 38 \\
\hline D & 23.5 & 23.63 & 6.5 & 22.38 & 4.76 & 15.04 & 36 \\
\hline
\end{tabular}

Fresh samples: $\mathrm{A}: 4^{\circ} \mathrm{C}(50 \mathrm{~h}) \rightarrow 10^{\circ} \mathrm{C}(28.5 \mathrm{~h}) \rightarrow 5^{\circ} \mathrm{C}(143 \mathrm{~h}) \ldots ; \mathrm{B}: 4^{\circ} \mathrm{C}(50 \mathrm{~h}) 10^{\circ} \mathrm{C}(28.5 \mathrm{~h}) \rightarrow 15^{\circ} \mathrm{C}(24 \mathrm{~h}) \rightarrow 25^{\circ} \mathrm{C}(8 \mathrm{~h}) \ldots ;$ Lightly salted : $\left(\mathrm{C}: 10^{\circ} \mathrm{C}(96 \mathrm{~h}) \rightarrow 15^{\circ} \mathrm{C}(96 \mathrm{~h})\right.$ $\rightarrow 5^{\circ} \mathrm{C}$.; D: $10^{\circ} \mathrm{C}(240 \mathrm{~h}) \rightarrow 5^{\circ} \mathrm{C}$, SLobs is the measured shelf life values, SLprd is the shelf life prediction value, relative error $=(\mathrm{SLprd}-\mathrm{SLobs}) \times 100 \% / \mathrm{SLobs}$

Table 7: The comparison of the potential SSOs

\begin{tabular}{llll}
\hline Sample type & Storage temperature & Potential SSOs in this paper & Potential SSOs in compared reference \\
\hline Fresh LYC & Low temperature & Shewanella putrefaciens & Shewanella putrefaciens [Gu, 2013, Zhu, 2016] \\
& Ambient temperature & Vibrio fluvialis Enterobacter spp. & Vibrio spp. in marine products[(Parlapani ,2013] \\
Lightly salted LYC & Low temperature & Proteus vulgaris & Proteus vulgaris[zhang, 2011] Brevundimonas diminute \\
& Ambient temperature & Vibrio alginolytica serratia & Vibrio spp. in marine products[Parlapani ,2013] \\
\hline
\end{tabular}


fish (Parlapani et al.,2013). Under ambient temperature, Vibrio and Enterobacter were the dominant groups, while Vibrio spp shared the main part at non-isothermal temperature in this paper, which suggested that Vibrio was frequently present in marine products(Seminario et al.,2011). The competition and interactions between the different bacteria in the spoilage flora therefore played a major role in determining the rate and the extent of fish spoilage. As for the lightly salted LYC Proteus vulgaris.

Brevundimonas diminute were potential SSOs under low temperature(Zhang et al.,2011).In this study, Shewanella, Vibrio and Enterobacter were observed to be the predominant microorganisms in fresh samples, and Proteus vulgaris, Vibrio alginolytica and serratia were the dominant microgranisms in light salted samples at different storage temperatures. Therefore, it might be an important measure to control the growth of Shewanella, Vibrio, Proteus vulgaris and Enterobacter these 4 kinds of microorganisms in order to extend the fish shelf life.

The shelf life prediction models was verified to predict the shelf life of the marine products. However, according to the relative error, the two models, the School-field model and the Exponential model, were superior to the Squareroot model, they could quickly and effectively predict the shelf life at the range of $0^{\circ} \mathrm{C} \sim 25^{\circ} \mathrm{C}$ in fresh LYC and the Exponential model was the best choose to predict the shelf life and the remaining shelf life of the lightly salted LYC among the three models. While García(Garcia, et al.,2015) used QIM model to reflect the quality of the retailed fresh hake, Zhu (Zhu, et al.,2016) used the modified Gompertz model to reflect the growth of the SSOs in order to predict the shelf life of the refrigerated LYC, and Powell and his team(Powell et al.,2015) chose a Belehradek-type model to reflect the growth data of spoilage bacteria on modified atmosphere packaged Atlantic salmon produced in Australia. There were many models being chosen to reflect the quality of marine products, to reflect the growth of the spoilage bacteria, or to predict the shelf life of the marine products. However, different marine products with different treatments and different storage conditions need specific models to implement the different function. This paper showed that, among the three models -- the Schoolfield model, the Exponential model and the Square-root model, which are most traditional and common methods for predicting the shelf life, the School-field model and the Exponential model were more suitable for the Pseudosciaena crocea than the Square-root model.

\section{CONCLUSION}

This paper studied the spoilage characteristics of Psendosciaena crocea with two treatments - fresh and lightly salted, which were mainly about the microbiological and chemical changes in the Pseudosciaena crocea during the storage at $0 \sim 10^{\circ} \mathrm{C}, 25^{\circ} \mathrm{C}$, fluctuating temperature with different storage time. Determined the dominated spoilage organisms and predicted the shelf life of the $L Y C$ with the mathematical models which were constructed with intelligent evaluation system.

(1) The result showed that in fresh $L Y C$, Shewanella was the dominant group at low temperature, while Vibrio spp. and Enterobacter were the dominant group at ambient temperature and at non-isothermal temperature. Vibrio shared the main proportion, while in lightly salted LYC, Proteus vulgaris, Vibrio alginolytica and serratia were the dominant group at low, ambient and fluctuating environment through $16 \mathrm{~S}$ rRNA sequencing and traditional Identification method.

(2) The shelf life of fresh LYC were $5.4 \sim 17.8$ days, 1.1 days and 4.6 9.3 days under the low, ambient and variable temperature, while the lightly salted $L Y C$ were 12.2 49.1 days, 4.2 days and 20.5 23.5 days under the low, ambient and fluctuating temperature.

(3) The School-field model and the Exponential model could predict the shelf life at the range of $0 \sim 25^{\circ} \mathrm{C}$ more quickly and effectively in the fresh LYC than Square-root model, while the Exponential model was better to predict the shelf life than the other two models of lightly salted $L Y C$

This paper can provide the supports for Digital mechanics of targeted microorganism and intelligently evaluating the safety and risk of fishery products.

\section{AUTHORS' CONTRIBUTIONS}

All the authors contributed equally to the writing of this paper, they were also involved in the overall work of experiments

\section{ACKNOWLEDGMENTS}

This work was supported by grants from Special Research Fund for the National Non-profit Institutes (East China Sea Fisheries Research Institute) under the contract number 2016M04, Shanghai municipal Natural Science Foundation(16ZR1444900), and Open Project Pro-gram of State Key Laboratory of Food Science and Technology,Nanchang University (No. SKLF-KF-201607).

\section{REFERENCES}

Alfaro, B. and I. Hernandez. 2013. Evolution of the indigenous microbiota in modified atmosphere packaged Atlantic horse Mackerel (Trachurus trachurus) identified by conventional and 
molecular methods. Int. J. Food Microbiol. 2: 117-123.

Berger, M. C. 2007. New Developments in Food Microbiology Research. Nova Science Publishers., New York.

Dalgaard, P., H. L. Madsen, N. Samieian. and J. Emborg. 2006. Biogenic amine formation and microbial spoilage in chilled garfish (Belone belone belone) - effect of modified atmosphere packaging and previous frozen storage. J. Appl. Microbiol. 101(1): 80-95.

Dalgaard, P., M. Vancanneyt, N. E. Vilalta, J. Swings, P. Fruekilde. and J. J. Leisner. 2003. Identification of lactic acid bacteria from spoilage associations of cooked and brined shrimps stored under modified atmosphere between 0 degrees $\mathrm{C}$ and 25 degrees $\mathrm{C}$. J. Appl. Microbiol. 94(1): 80-89.

Emborg, J., B. G. Laursen. and P. Dalgaard. 2005. Significant histamine formation in tuna (Thunnus albacares) at 2 degrees C-effect of vacuum-and modified atmosphere-packaging on psychrotolerant bacteria. Int. J. Food Microbiol. 101(3): 263-279.

Emborg, J., B.G. Laursen, T. Rathjen. and P. Dalgaard. 2002. Microbial spoilage and formation of biogenic amines in fresh and thawed modified atmosphere-packed salmon (Salmo salar) at 2 degrees C. J. Appl. Microbiol. 92(4): 790-799.

Garcia, M. R., C. Vilas, J. R. Herrera, M. Bernárdez, E. Balsa-Canto. and A. A. Alonso. 2015. Quality and shelf-life prediction for retail fresh hake (Merluccius merluccius). Int. J. Food Microbiol. 208: $65-74$

Gu, Q. Q, L. L. Fu, Y. B. Wang. and J. Lin. 2013. Identification and characterization of extracellular cyclic dipeptides as quorumsensing signal molecules from Shewanella baltica, the specific spoilage organism of Pseudosciaena crocea during 4 degrees $C$ Storage. J. Agric. Food Chem. 61(47): 11645-11652.

He, M., Q. Y. Guo. and B. G. Li. 2015. Freshness and bacterial composition changes in lightly salted Pseudosciaena crocea stored at different temperatures. Sci. Technol. Food Ind.24: 306310.

Heredia, N., I. Wesley. and S. Garcí. 2009. Microbiologically Safe Foods. John Wiley \& Sons., Hoboken, N.J.

Koutsoumanis, K. and G. J. E. Nychas. 2000. Application of a systematic experimental procedure to develop a microbial model for rapid fish shelf life predictions. Int. J. Food Microbiol. 60(2-3): 171-184.

Li T, Hu W, Li J, X. Zhang, J. Zhu. and X. Li. 2012. Coating effects of tea polyphenol and rosemary extract combined with chitosan on the storage quality of large yellow croaker (Pseudosciaena crocea). Food Control 25(1): 101-106.

Mcmeekin, T., J. Bowman, O. Mcquestin, L. Mellefont,T. Ross. and M.
Tamplin. 2008. The future of predictive microbiology: Strategic research, innovative applications and great expectations. Int. J. Food Microbiol. 128(1): 2-9.

Miks-Krajnik, M., Y. J. Yoon, D. O. Ukuku. and H. G. Yuk. 2016. Volatile chemical spoilage indexes of raw Atlantic salmon (Salmo salar) stored under aerobic condition in relation to microbiological and sensory shelf lives. Food Microbiol. 53: 182-191.

Nieminen, T. T, P. Dalgaard. and J. Bjorkroth. 2016. Volatile organic compounds and Photobacterium phosphoreum associated with spoilage of modified-atmosphere-packaged raw pork. Int. J. Food Microbiol. 218: 86-95.

Palino, M. 2007. Food Microbiology Research Trends. Nova Science Publishers., New York.

Parlapani, F. F., A. Meziti, K. A. Kormas. and I. S. Boziaris. 2013. Indigenous and spoilage microbiota of farmed sea bream stored in ice identified by phenotypic and 16S rRNA gene analysis. Food Microbiol. 33(1): 85-89.

PéRez-RodríGuez, F. and A. Valero. 2013. Predictive Microbiology in Foods. Springer., New York.

Powell, S. M., D. A. Ratkowsky. and M. L. Tamplin. 2015. Predictive model for the growth of spoilage bacteria on modified atmosphere packaged Atlantic salmon produced in Australia. Food Microbiol. 47: 111-115.

Quanyou, G., Y. Xianshi. and X. Zhong. 2006. Bacterial flora and identification of dominated spoilage organisms on cultured Pseudosciaena crocea at chilled storage. J. Fish. China 30(6): 824-830.

Seminario, D. M., M. O. Balaban. and G. Rodrick. 2011. Inactivation kinetics of vibrio vulnificus in phosphate-buffered saline at different freezing and storage temperatures and times. J. Food Sci. 76(2): E232-E239.

Vogel, B. F., K. Venkateswaran, M. Satomi. and L. Gram. 2005. Identification of Shewanella baltica as the most important H2Sproducing species during iced storage of Danish marine fish. Appl. Environ. Microbiol. 71(11): 6689-6697.

Xie, F. J., Q. H. Ai, K. S. Mai, W. Xu. and H. M. Ma. 2011. The optimal feeding frequency of large yellow croaker (Pseudosciaena crocea, Richardson) larvae. Aquaculture. 311(1-4): 162-167.

Zhang, X., Guo Q, Yang X. and X. Li. 2011. Quality evaluation and bacterial flore analysis of lighty salted Pesudosciaena crocea Products. Hum. Agric. Sci. 15: 121-123.

Zhu, J. L., A. F. Zhao, L. F. Feng. and H. Gao. 2016. Quorum sensing signals affect spoilage of refrigerated large yellow croaker (Pseudosciaena crocea) by Shewanella baltica. Int. J. Food Microbiol. 217: 146-155. 